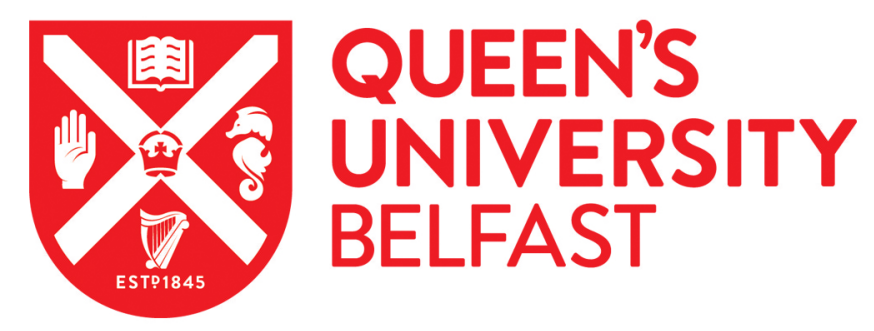

\title{
Studying administrative reforms through textual analysis: the case of Italian central government accounting
}

Liguori, M., Steccolini, I., \& Rota, S. (2018). Studying administrative reforms through textual analysis: the case of Italian central government accounting. International Review of Administrative Sciences, 84(2).

https://doi.org/10.1177/0020852315619023

\section{Published in:}

International Review of Administrative Sciences

\section{Document Version:}

Peer reviewed version

Queen's University Belfast - Research Portal:

Link to publication record in Queen's University Belfast Research Portal

Publisher rights

(c) 2015 Sage

\section{General rights}

Copyright for the publications made accessible via the Queen's University Belfast Research Portal is retained by the author(s) and / or other copyright owners and it is a condition of accessing these publications that users recognise and abide by the legal requirements associated with these rights.

Take down policy

The Research Portal is Queen's institutional repository that provides access to Queen's research output. Every effort has been made to ensure that content in the Research Portal does not infringe any person's rights, or applicable UK laws. If you discover content in the Research Portal that you believe breaches copyright or violates any law, please contact openaccess@qub.ac.uk. 


\title{
Studying administrative reforms through textual analysis: the case of Italian central government accounting
}

\begin{abstract}
This paper contributes to the literature on public-sector reforms by proposing textual analysis as a useful research strategy to explore how reform archetypes and related ideas are deployed in the parliamentary debate and regulations advancing reforms. Public Administration (PA) (Wilson 1887; Weber 1922), New Public Management (NPM) (Hood 1991, 1995; Dunleavy and Hood 1994; Ferlie et al. 1996) and Public Governance (GOV) (Osborne 2010; Rhodes 1997) can be depicted as three different archetypes providing characteristic administrative ideas and concepts (i.e. interpretive schemes) and related tools and practices (i.e. structures and systems) which lead reforms. We use textual analysis to look into more than twenty years of Italian central government accounting reforms and investigate how the three administrative archetypes have evolved, intertwined and replaced each other. Textual analysis proves a useful tool to investigate reform processes and allows highlighting that in neo-Weberian countries, such as Italy, NPM and GOV, far from being revolutionary paradigms, may represent fashionable trends that did not leave significant traces in the practice and rhetoric of reforms. These results also suggest interesting implications for practitioners and policy makers.
\end{abstract}

Keywords: accounting reforms, reform archetypes, Italy, new public management, public governance, textual analysis. 


\section{Studying administrative reforms through textual analysis: the case of Italian central government accounting}

\section{Introduction}

Public sector reforms have been the subject of intense academic curiosity over the last decades, driven by a supposed shift in administrative models, from Public Administration (PA) (Wilson 1887; Weber 1922) to New Public Management (NPM) (Hood 1991, 1995; Dunleavy and Hood 1994; Ferlie et al. 1996; Olson et al. 1998; Pollitt and Bouckaert 2004; Skelcher et al. 2005) and, more recently, to Public Governance (GOV) (Osborne 2010; Rhodes 1997). In this debate, a lot of attention has been devoted to the contents of reforms and their implementation. However, less consideration has been given to how reforms are made sense of and discussed by those responsible for designing, approving and advancing them in the legislative process, and whether and how PA, NPM and GOV intertwine and relate to each other in the reform rhetoric. In addressing this gap, our paper, which draws on archetype theory (Greenwood and Hinings 1993, 1996; Liguori and Steccolini, 2012; Liguori, 2012a, 2012b) as a relevant conceptual lens, shows that textual analysis is a fruitful method to study how different administrative archetypes or models are deployed in the parliamentary debate and in regulations that put forth reforms in central governments.

The analysis offers a threefold contribution. First, we analyse reform archetypes relying on textual analysis. To the authors' knowledge, rarely has this methodology been adopted to study administrative processes and reforms or to investigate management practices in the public sector (for exceptions, see McGrath 2009; Hyndman et al. 2014). We develop the technique to explore whether and how PA, NPM and GOV archetypes replaced, supplemented or integrated each other. Second, in our study we adopt an archetypical view of administrative models, which allows us to look not only at the practices, structures, systems that are advanced by reforms, but also at their underlying interpretive schemes, i.e., the underlying systems of beliefs and values. Third, we consider a type of administrative reform, accounting, that bears particular significance and represents an interesting setting to explore the use of new reform ideas and their advancement. Accounting reforms (dealing with financial accounting, budgeting and/or performance measurement systems), far from being neutral, represent practical translations of general ideas, values and principles to specific circumstances and into specific tools, systems and procedures. Accounting systems and ideas 
embody and reflect the specific principles and values governing public organisations, and, in turn, may contribute to affect changes in the culture, meanings and values (Lapsley 1999; Liguori and Steccolini 2012, 2014; Liguori et al. 2012). The accounting reforms that took place over the last few decades are claimed to have played a central role in public-sector change processes, at both central and local levels (Olson et al. 1998; Lapsley, 1999; Liguori et al., 2012; Skelcher et al. 2005).

The context of this study is the Italian Central Government. The paper explores reforms with novel methodological lenses in a country that has been described as a mild adopter of managerial reforms and a neo-Weberian state (Capano 2003; Kuhlmann 2010; Ongaro 2011). This will provide new evidence on the multifaceted ways thorough which reform archetypes can be translated into political debates, norms and administrative documents. The following section reviews the relevant literature on public sector reforms and presents the research question of the paper, advancing the case for the adoption of an archetypal view and the use of textual analysis. Section three presents textual analysis as a research methodology, and section four specifies the methods adopted in our study. Section five and six, respectively, present and discuss the results. Finally, section seven draws some conclusions, discusses the limitations of our study and new possible research avenues.

\section{Public administration, New Public Management and Public Governance: archetypes and ideas}

PA, NPM and GOV have been the subject of intense debate in the managerial literature on public sector reforms and in organisational institutional literature over the last decades. According to scholars, PA, NPM and GOV can be depicted as three administrative models reflecting different combinations of administrative values and ideas (Hood 1991, Pollitt and Bouckaert 2011), influencing the trajectory of the reforms, and subsequently translated into related administrative tools, structures and systems. With reference to both their values and systems, some authors have identified these three models as administrative reform archetypes (Hammerschmid and Meyer 2005; Kirkpatrick and Ackroyd 2003; Liguori 2012a, 2012b; Liguori and Steccolini 2012).

The PA paradigm (Wilson 1887; Weber 1922) has dominated the public sector scene from the late XIX century to the early Eighties, until managerial and market principles started to seep into the public sector, gradually becoming the basis and inspiring source for NPM (Hood 1991, 1995; Dunleavy and Hood 1994; Ferlie et al. 1996; Olson et al. 1998; Pollit and Bouckaert 2004; Skelcher et al. 2005). A significant body of literature has pointed to global 
convergence of public sector reforms (Pollitt 2001; Bouckaert 2007; Christensen and Lægreid 2007; Kickert 2008). In parallel, however, other scholars have increasingly recognized that global reform trends have been translated with significant local variations (McNulty and Fischer 2004; Hammerschmid and Meyer 2005; Liguori and Steccolini 2012; Liguori 2012a, 2012b) and unexpected (Hood and Peters 2004; Lapsley 1999, 2008, 2009) and divergent results (Etherington and Richardson 1994; Hood 1998; Barzelay 2001; Lounsbury 2001; Pollitt and Bouckaert 2011; Liguori and Steccolini 2012). Some have pointed out that in Continental European countries, including Italy (Capano 2003; Kuhlmann 2010; Ongaro 2011), a comprehensive 'paradigm shift' from the Weberian bureaucracy to the NPMinspired administration has not occurred. This unexpected reform outcome is also identified with the raise of a neo-Weberian model ${ }^{1}$, where classical Weberian elements and new NPMrelated features are mixed, giving rise to a specific Continental-European version of managerial reforms (Bouckaert 2006; Kuhlmann 2010). A different voice is represented by Osborne's $(2006,2010)$ argument that NPM has only been a transitory stage in the evolution from PA to GOV. GOV emphasises the existence of a plural (where multiple interdependent actors contribute to the delivery of public services) and a pluralist (considering multiple processes to inform policy-making - Marsh and Rhodes 1992; Börzel 1997; Lynn and Heinrich 2001; Peters 2008) state.

The supposed shift in public-sector administrative models has been at the centre of a broad debate, yet there is no agreement on the extent of the actual replacement of PA ideas with NPM and GOV ones, nor on whether NPM merely represents a transitory set of tools and techniques (Osborne, 2006). The contributions discussing NPM and GOV describe their main characteristics (Marsh and Rhodes 1992; Ferlie et al. 1996; Pollit and Bouckaert 2004; Peters 2008) and identify (theoretically and empirically) their positive and negative effects (Dunleavy and Hood 1994; Lapsley 2008, 2009; Hood and Peters 2004), thus focusing on the contents of reforms, on their implementation, and the gaps therein. With some recent exceptions (Fattore et al. 2012; Hyndman et al. 2014), less attention has been given to how reforms ideas and values are made sense of and discussed by those responsible for designing, approving and translating them during the legislative process, and whether and how these ideas and values relate to each other. Moreover, from a methodological viewpoint, most

\footnotetext{
${ }^{1}$ The neo-Weberian model of state features a rediscovery of rules and legal principles, where business-like methods have a role, but the state, with its own rules, methods and culture, remains the key actor (Pollitt and Bouckaert 2011).
} 
contributions on reforms tend to adopt a comparative approach, laying their analysis on the grounds of historical explanations (Kuhlmann 2010; Ongaro 2011; Kickert 2005) or normative (Hood and Peters 2004; Marty et al. 2006), descriptive and exploratory analyses (Pollitt and Bouckaert 2011; Cheung 2012).

Recent studies (Liguori 2012a, 2012b; Liguori and Steccolini 2012), focusing on the organisational level, have drawn on archetype theory (Greenwood and Hinings 1993, 1996) to investigate accounting change within public sector organisations. An archetype is a set of structures and systems that reflects a single interpretive scheme, made up of ideas, beliefs and values (Greenwood and Hinings 1993). According to this view, the outcomes of change (and reforms) are filtered by organisations through an internal process of interpretation and attribution of meanings, where change itself is defined by the shift between archetypes (Liguori and Steccolini 2012) and can be conceptualised looking at two distinct levels: systems and structures vs. interpretive schemes. We posit that archetype theory provides a structured framework to identify and study the three administrative models (PA, NPM and GOV) also in the political debates that take place within governments (see the table in Appendix). Indeed, it appears particularly suited to account for the importance of underlying ideas and beliefs in affecting change in practices. This approach is also consistent with public policy literature highlighting the importance of 'ideas' in an 'ideational stance' (Sabatier 1999: 9). According to Sabatier (1999), for instance, ideas appear in the form of policy beliefs, which are diffused by processes of policy-oriented learning and major policy change that occurs through windows of opportunity. Similar to archetype theory, the ideational approach proposes the distinction between different levels of change (structures and systems vs. ideas and values) ${ }^{2}$. Archetype theory, which developed within the institutional stream of organisation studies, can prove particularly suited to look at administrative reforms, which are specifically aimed at changing organisational structures and systems by either relying on extant interpretive schemes or proposing new ones.

\section{Textual analysis as a methodology for exploring reforms}

In this paper we propose that textual analysis represents a valuable methodological approach to improve our understanding of the development and use of different archetypes at the

\footnotetext{
${ }^{2}$ We thank one of the reviewers for this useful insight.
} 
organisational and political level. In particular, we take into consideration the complexity through which PA, NPM and GOV structures and systems, and ideas and values, are transposed in political debates, laws, norms, and provide a better understanding of their developments and intertwining. Textual analysis has been so far adopted by researchers working in different disciplines of social sciences (O'Connor 1995; Loughran and McDonald 2011), including organisational and managerial studies (Hardy 2001). Rarely has this methodology been used to study administrative processes and reforms (for exceptions see McGrath 2009; Hyndman et al. 2014). PA, NPM and GOV can be fruitfully captured through the use of textual analysis. In this section we discuss how textual analysis can contribute to investigate administrative reform archetypes and how it was specifically used in this study.

Textual analysis is a resource for social research that includes a range of methodologies, such as narrative, content, discourse or rhetorical analysis (Fairclough 2003; Fischer 2003). Textual analysis can focus on a few selected features of the text or many features simultaneously, allowing investigating distinctive patterns of occurrence, co-occurrence or collocation between words. This ensures an 'open process', which can enhance dialogue across disciplines and theories (Fairclough 2003).

In the light of the aims of the study, the usefulness of textual analysis (in particular, discourse analysis) lies in the methodological support it provides to shed new light on administrative archetypes and related reform ideas. PA, NPM and GOV, indeed, can be conceptualised, as proposed by archetype theory, as three different sets of systems/structures and related interpretive schemes, with each providing characteristic standard narratives, vocabularies, ideas, concepts or instruments (Mills, 1940). Textual analysis can help decipher changes in the existing ideas and structures, resulting from administrative reforms that are constructed on specific discourses. It, thus, provides a means to analyse how both ideas and structures evolve over time (Van Thiel 2014). Discourse analysis, in particular, posits that it is impossible to strip a discourse (i.e. a set of characteristic narratives, ideas and instruments) from its broader context (Fairclough 2003). This can be particularly useful to highlight the arguments present in the political discussion, together with the rhetoric accompanying reforms, and to overcome the well-known limitations (e.g. focus on literal contents of the documental source) of the mere content analysis (Fattore et al. 2012). In this sense, political debates, laws and administrative documents incorporate the linguistic texts, social practices and socio-cultural contexts in which they are embedded and have been, thus, chosen as the basis of our analysis. Official documents and transcripts concerning changes in central- 
government accounting (financial accounting, budgeting and/or performance measurement) systems were coded to explore what discourses and arguments shaped the rhetoric of the legislative reforms processes and how these developed. The original transcripts of political and administrative discussions represent the arena where the main actors put forth their ideas to support or hamper a certain change. Accounting reforms, in particular, can be considered an 'expert talk'. We, thus, expect official documents and debates to be the carriers of the most relevant ideas and values discussed around them.

\section{Methods of the study}

In this paper, textual analysis, and, more specifically, discourse analysis is used to study the evolution of reform archetypes and the related administrative discourses present in centralgovernment accounting debates from 1988 to 2010. Italy has a strong legalistic administrative tradition and represents a relevant context of study, since it has been often identified as a typical example of Napoleonic country and a medium-intensity adopter of NPM ideas (Hood 1991, 1995; Capano 2003; Pollitt and Bouckaert 2004; Ongaro 2011; Fattore et al. 2012, Bellè and Ongaro 2014). Moreover, being a civil-law country, Italy has always relied on laws and administrative acts to adopt reforms (Panozzo 1998).

The documents considered were representative of the entire legislative process (Borghetto 2014), concerning changes in financial accounting, budgeting and/or performance measurement systems, and were analysed taking into consideration both the ideas and values discussed and the (new) structures and systems to be established. We analysed a total of 40 documents and 1,443 pages related to accounting systems and reforms: transcripts of the first and the final law discussions (which represented also all the discussions taken in both Chambers of Parliament); all parliamentary technical committee reports discussing modifications to the draft laws; all reform laws published in the Official Gazette; all administrative guidelines or commentaries to the laws (typically called 'Circolare' and enacted by the Ministry) and legislative-decree laws issued by the government and concerning the directions for the enactment of the related law. These documents were collected from the institutional archives of the two parliamentary chambers, the Chamber of Deputies and the Senate.

PA, NPM and GOV were conceptualised under the lenses of archetype theory, drawing on existing studies, where their characteristics are discussed (Hinings and Greenwood 1988; 
Pollit and Bouckaert 2004; Hammerschmid and Meyer 2005; Schedler and Proeller 2007; Osborne 2010; Liguori 2012b; Liguori and Steccolini 2012). Each archetype was operationalised at two different levels: i) ideas and values being discussed/proposed, and ii) accounting structures and systems actually being decided upon (see the Appendix). As a result, a list of indicative keywords and cues was identified and agreed by the researchers and then used by them to code the documents.

The unit of analysis was the paragraph, which represents 'a collection of meaningful sentences' (Guthrie et al. 2003, p. 10). In particular, each paragraph was read in its entirety to assess whether the argument made was used in favour (code 1) or against (code 2) a certain administrative model. For each of the latter, two possible codes were thus defined: PA/NPM/GOV 1 (in favour) or PA/NPM/GOV 2 (against); for each paragraph multiple codes were allowed.

The relative prevalence of the discourses related to each archetype was measured by the occurrence of different cues within each paragraph (e.g. when four different NPM1 cues occurred in a paragraph, the paragraph was "weighted" as NPM1*4); their co-occurrence was identified by binary codes for each paragraph indicating whether specific discourses were presented together or not (e.g. when one NPM1 cue occurred four times in a paragraph together with two PA1 cues, the paragraph was counted only once). Atlas.ti.6, was used to ensure a systematic approach to the analysis, to share and update cues simultaneously, assign multiple codes to the same paragraph, and thus creating networks of analysis and tables of cooccurrences across them.

As all research approaches, also textual analysis presents some limitations that must be handled carefully. The main limit of all textual-analysis approaches is the need of demonstrating the reliability of the tools used to collect and code data and the consequent validity and replicability of inferences drawn from them (Milne and Adler 1999). Reliability involves stability (ability to code data the same way over time), reproducibility (extent to which coding is the same when multiple coders are involved) and accuracy (quality of coding performance against a predetermined standard set by a panel of experts, or known from previous experiments and studies, Krippendorff 1980). To ensure reliability, well specified decision categories and rules were defined in advance, multiple coders were used and discrepancies between the coders were re-examined. 


\section{Findings}

This section presents the story of the changes and the results of the discourse analysis carried out on the Italian Central Government's official documents discussing accounting reforms from 1988 to 2010 . For analysis purposes, the results are divided into three periods, which (following previous literature) also correspond to the decades when the three administrative archetypes came to the fore: the Eighties, the Nineties and the Two-Thousands. FIGURE 1 below shows the evolution of the three administrative archetypes and the related discourse cues over time.

\section{Insert FIGURE 1 here}

\section{The Eighties}

The Italian central-government budgeting, accounting and reporting systems have been traditionally cash and commitment-based, with the main purpose to ensure budgetary compliance and control over expenditure (see TABLE 1). One of the major central government accounting reform was carried out in 1988, when the Economic and Financial Plan (EFP) was introduced to strengthen long-term planning and lower the binding strength of a single financial law bill. The EFP was to be implemented through the budget law and the annual and multiyear budgets. According to this new framework, the annual budget decisions would be a consequence of a series of legislative and non-legislative acts, defined as publicfinance documents (EFP, budget law, etc.).

\section{Insert TABLE 1 here}

In the same period, the textual analysis shows that the prevailing arguments used to promote change in accounting structures and systems were related to the traditional PA ideas (see TABLE 2, summarising the discourse occurrences per year as a percentage of the total, normalised by the number of relevant documents issued each year). For instance:

'We are all aware of the importance of the last revision of the budget, from which the final report stems and which identifies the establishments of amounts receivables and the amounts to be paid. It prescribes a series of requirements to be complied with for next year's budgeting procedures, especially for the preparation of the Economic and Financial Plan. I, 
thus, recommend to the Chamber the approval of my amendment... ${ }^{3}$ (First discussion of the Chamber of Deputies, $6^{\text {th }}$ July 1988).

The most frequently co-occurring codes during the Eighties were PA1 and NPM1 (i.e. arguments in support of both the "old" PA and the 'new' NPM - TABLE 3). Only a very few sections of the 1988 documents highlighted arguments against the use of the traditional accounting tools (i.e. PA2):

'Mr President, the 1978 law that we are going to reform was born when in the Parliament there was a widespread idea that there was no interest in discussing the budget. Ample was the sensation of complete impotence: the budget was a mere document for recording actions already taken. The French defined this situation as the "three Ls" of budgeting, liturgie, litanie, léthargie, and thus it had to be reformed. As a consequence, the law aims at bringing back accessibility, flexibility and decisional capability to budgets' (First discussion of the Senate, $26^{\text {th }}$ July 1988).

Insert TABLE 2 and TABLE 3 here

\section{The Nineties}

In 1997, law no. 94 introduced a significant reform in central government accounting by simplifying the structure of the budget and introducing accruals and cost accounting tools. Consistent with NPM ideas, a clear distinction was made between the political and the managerial budgets. The former, to be approved by the Parliament, was significantly aggregated; while the latter was a further articulation of the political budget. The cost accounting system required the definition of cost and responsibility centres in each Ministry and of related efficiency and effectiveness indicators. The new (accruals) and the old (cashand commitment-based) accounting systems had to be integrated, and their reconciliation highlighted. Through documents called 'preliminary notes', each Ministry was asked to

\footnotetext{
${ }^{3}$ The authors would like to stress that the sentences quoted in the paper do not represent their personal views on accounting systems, reforms and ... syntax! The authors tried to give a translation which was as adherent as possible to the original Italian text.
} 
identify its own objectives and related resources and indicators. This new costing system was enacted and put into practice in 1999 through the 'Circolare 32'.

Despite the legislative attempt to push forth new managerial and performance measurement ideas and tools, the analysis still highlights the prevalence of a discourse built around the traditional PA archetype (TABLE 2). Differently from the Eighties, however, arguments supporting PA and NPM tended to be kept separate, as shown by the fall in the co-occurrence of PA1 and NPM1 cues within the same paragraph (an average 47.33 per document in 1988 vs. 21 in 1997 -TABLE 3). Following the changes, in 1999 PA finally lost ground to NPM (TABLE 2) and a peak in ideas and values supporting or describing the new managerial structures and systems could be identified. For instance:

'Managers are allocated tasks concerning direction, management, spending, organization and control. They are responsible for administrative activities, management and results' (Circolare 32, 1999)

PA was still present, but now in the background. Both PA ideas and values (such as the importance of complying with law requirements and sticking to formal administrative procedures) and the related structures and systems (e.g. cash-and commitment-based accounting) were still used to recall PA long-lasting importance. As a consequence, there were again only a very few paragraphs using terms such as 'cash', 'expenditure' or 'bureaucratic' to challenge the old model (i.e. PA2 - TABLE 2). Consistently, in 1999 the cooccurrence between NPM1 and PA1 jumped up to 139 counts/paragraphs per document. This highlights that, despite the increase in NPM-cues occurrence, arguments supporting PA were still present and used as a basis to encourage managerial changes. For instance, the introduction of accruals accounting was mostly legitimised since required by law:

'The norms, besides introducing an innovation in the budget structure, introduce accruals bookkeeping as far as Government services and activities are concerned' (Circolare 32, 1999)

\section{The Two-thousands}

In 2005 arguments in favour of NPM and PA almost balanced (TABLE 2). A late commentary related to the 1997 (no. 94) law re-established the importance of PA structures 
and systems (cash and commitment bases of accounting), together with a renewed focus on the bureaucratic procedures to be followed. At the same time, however, the commentary also referred to NPM tools (such as cost accounting).

The 1997-1999 reform brought about significant innovations, but was also criticised because: the new budgeting process relied on incremental logics, with weak long-term orientation; the political budget presented more than 1,500 items of expenditure; and there was an excessive presence of ex-ante controls, with little attention paid to non-financial results. As a consequence of these shortcomings, in 2007 (through the 'Circolare 21') the traditional budget structure was modified again to guarantee a closer link between allocated resources and pursued actions, consistently with NPM ideas. In 2007 also the cost accounting system was partially revised. Costs were now recorded by nature, centre, mission and programme and were mirrored in the accrual budget. In parallel, an annual spending review to assess the actual Ministries' needs was set in place. Like in 2005, through the 2007 parliamentary discussions and documents, modifications were made to the old cash- and commitment-based reporting structure (with the adoption of the $\mathrm{COFOG}^{4}$ nomenclature). Although these changes were mainly related to PA, NPM was still present, representing more than $40 \%$ of the overall cues (TABLE 2), and was mainly co-occurring with PA1 (TABLE 3).

In 2009, the role of the spending review process and the cash-based accounting system were further strengthened to adjust to the European Union's financial and budgetary arrangements, and to align the central and local government budgeting processes. The main resulting change was the transition towards a cash-based-only budget ${ }^{5}$. In 2010 a commentary to the 2009 reform was also issued. The analysis shows that in 2009 and 2010 PA1 arguments overtook those in favour of NPM again (TABLE 2). In the 2009 documents, the combination of PA1 and NPM1 cues occurred 58.06 times; this number more than doubled (132 times - TABLE 2) in 2010. Here the data also show the highest co-occurrence of PA1 (in favour) and NPM2 (challenging NPM ideas) codes of the whole period considered (with an average of 7 per document - TABLE 3). This confirms the return of a strong PA orientation in the Italian debate.

\footnotetext{
${ }^{4}$ Classification Of the Functions Of Government.

${ }^{5}$ In 2009 the law no. 196 imposed the shift to a cash-based budget only. In 2011 a subsequent law (no. 39) set aside this possibility strengthening the role of cash budgeting within a mixed system (cash- and commitmentbased).
} 
But what about GOV? Surprisingly, over the 22 years analysed, GOV-related ideas always represented the least important and most marginal discourse, with concepts such as transparency, stakeholders and networks scantly quoted and not always present in the documents. While remaining poorly visible as a self-standing discourse, since 2007 ideas in favour of GOV have been increasing (although always keeping a low base $-8.1 \%$ and $8.7 \%$ in 2009 and 2010 respectively - TABLE 2) and often used in combination with the other two archetype cues (in 2010, in particular, GOV1 co-occurred 37 times per document with PA1 and 34 times with NPM1, the highest rates over the 22 years - TABLE 2). This might suggest that GOV is starting to seep into the Italian scene, but only in (and with the) support of the more established PA (especially) and NPM.

\section{Discussion: from PA to NPM and back}

Our analysis shows that two discourse 'peaks' (in 1999 and in 2009) can be identified in the debate around Italian central-government accounting reforms. In 1999, NPM overtook PA arguments for the first (and last) time, whereas their importance swapped again in 2009. In 1999 the reform concerned the implementation of the new cost and accrual accounting system previously passed in 1997. The main cues of the year related to 'cost' (288 counts, representing $1.74 \%$ of the 1999 document words), 'cost accounting' (185 counts, 1.05\%) and 'managerial responsibilities' (present 109 times, 0.66\% of the 1999 document words), mirroring clear NPM ideas and values. For instance:

'The importance of the new process requires the full cooperation and participation of all government departments that are first concerned with the budget formulation by cost centres for the year 2000. In this context, it is necessary for the State Administrations to organize offices and procedures to enable the most effective performance of new activities, including the identification - for each cost centre - of the officials devoted to the tasks of acquisition, detection, monitoring and transmission of cost information.' (Circolare 32, 1999)

Cues supporting the introduction of NPM ideas in the Italian political debate paralleled positive mentions of the new accounting structures and systems (e.g. the managerial budget mentioned 56 times, $0.34 \%$ of the 1999 document words). The first effects of the managerial reforms implemented in the Nineties became, thus, visible in the Government's everyday life and operation, as well as in their decision-making processes: 
'The change to the organizational model, together with the support of a specific accounting instrument - the cost accounting system based on cost centres - allows Administrations to achieve the constant and simultaneous monitoring of operating costs, and to initiate an ongoing dialogue with the Treasury for evaluations related to financial planning and preparation of the annual budget.' (Circolare 32, 1999)

In 2009 the wave of managerial reforms seemed to be forgotten in favour of a return to the old PA. In particular, the reform process went back to focus on and strengthen the role of cash-based accounting. As a consequence, the main discussion revolved again around traditional PA structures and systems, such as the importance of enforcing the new accounting 'rules' (2,751 counts, representing $0.93 \%$ of all 2009 documents words):

'The results of this debate pose as a matter of evident urgency the need to reform the accounting rules in order to adapt the regulatory framework to recent institutional changes and conditions of public accounts.' (Transcript from the Senate's Committee discussion on Law 196, 2009, 26th March 2009)

Also the focus on 'cash' (334 counts, $0.12 \%$ of all 2009 documents words) and 'expenditure' $(1,289$ counts, $0.48 \%)$ re-emerged with new and increased strength:

'The bill, on the one hand, systematizes the innovations made to the budget during the last two years; on the other hand, it delegates Government to complete the reform, also ensuring a gradual transition from the preparation of the budget in terms of obligation and cash, to one in terms of cash only. From another perspective, it confirms the non-binding function of the resources allocated to the programs of each mission, with the breakdown of expenditures into binding and non-binding for each program' (Transcript from the Chamber of Deputies' Committee discussion on Law 196, 2009, $9^{\text {th }}$ November 2009)

Looking at the evolution of the accounting reforms over time, the evidence seems to suggest a long-lasting commitment of the Italian Central Government to traditional PA ideas and accounting systems. An explanation for this could be found in the Italian civil-law tradition, which is also reflected in the predominant juridical background of Italian bureaucrats and politicians (Kickert 2005; Ongaro 2011). The PA archetype, which was already established 
before the Nineties, tends to survive and reproduce itself and is always present in the background of every accounting reform. Even when a formal managerial change is required, there is little incentive to replace the old ideas and systems, which are never really put under scrutiny, but rather reaffirmed under different shapes and expressions (e.g. by stressing the role of law and rules). For instance:

'Accrual-accounting bookkeeping and outputs are used also to define the budget proposals, to better allocate resources, to plan financial activities, to monitor the financial impacts of budgetary changes and cost and legislative requirements in the areas for which the Administrations are responsible.' (Decree law 279, 1997)

The introduction of NPM-like changes seems to be the condition for the old PA to survive and reproduce itself. A similar pattern can be seen in the development of GOV ideas, which increase over time, but always in combination with the other two archetypes, especially PA. This provides evidence to Pollitt and Bouckaert's (2011) argument that we may be currently witnessing a third stage of reforms, with the latter, rather than being GOV-dominated, characterised by a neo-Weberian upsurge. Old PA ideas would be, thus, reinterpreted adjusting existing structures and systems and shifting from the view of a closed system of public administration to an open one, where external transparency, participation and inclusion are pushed forward. The analysis shows that, while in the late Eighties these ideas were relatively neglected, in the late Nineties and in the Two-thousands they are introduced and reinterpreted in a bureaucratic way. For instance:

'The European accounting system requires a more and more modern and efficient management of public spending and related Member States' policies. The fiscal federalism, as implemented in Italy, needs standard criteria in order to guarantee the participation of all the institutions in the management of the national tax system, from the municipalities, to the Regions, the State, and all those who belong to the public administration system and manage public spending. ' (Transcript from the Senate discussion on Law 196/2009, 16th June 2009)

The Italian context clearly highlights what Tomasi di Lampedusa suggested in his novel "Il Gattopardo": 'If we want things to stay as they are, things will have to change' (Tomasi di Lampedusa 1960, p. 40). Both NPM and GOV appear to have been engrafted into the preexisting PA model, which, in turn, has accompanied and buffered the introduction of all the 
subsequent reforms. This has probably made the latter appear less threatening to politicians, bureaucrats and other stakeholders involved in the process, and, at the same time, allowed the original bureaucratic features to be re-established and perpetuated under the new disguise of the time.

\section{Conclusions}

This paper contributes to public-sector reform literature by showing how textual analysis can help achieving a better understanding of administrative reform archetypes (namely, PA, NPM and GOV) and the way their related ideas are developed and used in the political debate. This has been shown through the textual analysis of documents concerning the Italian centralgovernment reforms over the last two decades. We focused, in particular, on a type of reform, accounting, that has played a major role in recent reforms, and that, far from representing a neutral process, can display the practical translations of general ideas, values and principles to specific circumstances and into specific tools, systems and procedures. Moreover, we considered a setting, the Italian one, which is described as neo-Weberian implementer of NPM changes (Pollitt and Bouckaert 2011; Ongaro 2011; Fattore et al. 2012, Capano, 2003) and where the intertwining of different administrative models appears to be particularly relevant.

Textual analysis represents a useful research tool to contribute to the scholars' debate on PA, NPM and GOV reform processes. More specifically, drawing on archetype theory, our paper highlights the prevalence of the bureaucratic archetype, with a substantial stability of the related PA tools, ideas and principles, notwithstanding the multiple attempts at introducing more NPM- and GOV-like accounting tools and values in a country with a legalistic administrative tradition. If the literature has often described the 'evolution' from PA to NPM and GOV (Marsh and Rhodes 1992; Milward and Provan 2003; Peters 2008; Osborne 2010), the analysis suggests that NPM and GOV cannot be considered (at least so far) as having the same significance as the PA archetype. In Italy, more than a replacement, there has been the coexistence, over time, of multiple ideas and values with a lasting and significant predominance of the traditional PA archetype. NPM and GOV, far from being new revolutionary paradigms, can be described as (more or less) fashionable trends that do not leave a significant trace in the practice and in the rhetoric of reforms. Moreover, PA, far from being eradicated by the others, remains quite stable over time in its main ideas and arguments, although it adapts its structures and systems to the new contexts and requests chameleon-like, 
absorbing and taking on features of the incoming most fashionable ideas (Abrahamson 1996; Christensen and Lægreid 2011; Liguori 2012b).

The analysis stresses the relevance of textual analysis in better understanding public-sector managerial (and accounting) reforms, highlighting also their interdisciplinary potential. As shown in our study, a clear conceptualisation of the object of analysis (in this case the PA, NPM and GOV, here identified as archetypes through both their proposed ideas and values and structures and system; operationalised through a list of keywords and cues) allow researchers to grasp the complexity through which administrative models are interpreted (coding stage) and contextualised (analysis stage) in discourses by organisations and political actors in the rhetoric of reforms.

Another important implication of this methodological choice lies in the versatility of textual analysis. Indeed, it helps highlight how discourses evolve over time through the analysis of large quantities of documentary materials over a long period of time. In addition, the identification of arguments supporting or criticising a particular archetype, as well as the creation of tables of occurrence and co-occurrence, open the way to a finer-grained study of both archetypes and reform processes at a specific point in time or in terms of their evolution (replacement or co-existence) over time.

This paper holds important implications also for practice and policy making. From a policy perspective, we highlight that in contexts based on civil-law traditions, with a unitary but increasingly decentralised structure and a coalition-government system (Pollitt and Bouckaert 2011), the introduction of new reforms can be slow and difficult. This is often more successful when the discourses surrounding change are respectful of extant PA ideas and values, which, far from being discarded, remain well rooted in the public arena. Decision makers should thus pay greater attention to the administrative archetypes and the arguments used to challenge, support, legitimise and advance reforms, and also be aware of their possible interactions. From an organisational and managerial point of view, this study underlines the importance of reassuring civil servants and politicians on the consistency of the 'new' proposed models with the 'old' ones they have been accustomed to. In some cases, using the traditional PA language to explain and introduce new ideas and tools can make change more acceptable. However, this has to be balanced off by an actual change in the systems and structures, using continuity to bring disruption and avoiding merely formalistic approaches. 
Our work, as any piece of research, presents limitations and offers stimuli for the development of new studies. First of all, our results are influenced by the strong legalistic tradition of the country selected. Future studies might extend the use of textual analyses to investigate and compare reform processes in countries with different administrative traditions (O'Toole and Meier, 2014). Second, our focus on reform archetypes and discourses at the legislative and political level excludes other arenas, such as the media or the academic debate. Moreover, ideas and values may be only loosely coupled with the actual reform implementation. Future studies might explore the reform discourses used by different actors at different levels, and those adopted by mass and social media; they might extend the textual analysis to other actors involved in the policy-making process (civil servants, interest groups, experts, policy analysts.) to explore whether and how ideas impact on policy outcomes. Finally, other research avenues might involve the study of archetypes over time and at different levels of government, looking at the dialectic development of reforms between central and local administrations. 


\section{References}

Abrahamson E (1996) Management fashion. Academy of Management Review, 21(1): 254-85. Barzelay M (2001) The new public management: Improving research and policy dialogue, Vol. 3, Berkeley: University of California Press.

Bellè N. and Ongaro E (2014) NPM, administrative reforms and public service motivation: improving the dialogue between research agendas, International Review of Administrative Sciences, 80(2): 382-400.

Borghetto E (2014), Legislative processes as sequences: exploring temporal trajectories of Italian law-making by means of sequence analysis, International Review of Administrative Sciences, 80(3): 553-576.

Börzel T (1997) What's so special about policy networks? An exploration of the concept and its usefulness in studying European governance. European Integration Online Papers, 1.

Bouckaert G (2006) Towards a Neo-Weberian Administration'. In: Bagumil J, Jann W and Nullmeier F. (Hrsg.) Politik und Verwaltung. PVS Politische Vierteljahresschrift. Sonderheft 37/2006. Deutsche Vereinigung fur Politikwissenschaft. Wiesbaden: Verlag fur Sozialwissenschaften (354-372).

Bouckaert G (2007) Cultural characteristics from Public Management reforms worldwide. In: Schedler K, Proeller I, editors. Cultural aspects of Public Management reform. Amsterdam: Elsevier (29-64).

Capano G (2003) Administrative Traditions and Policy Change: When Policy Paradigms Matter. The Case of Italian Administrative Reform during the 1990s'. Public Administration, 81(4): 781-801.

Cheung ABL (2012) One country, two experiences: administrative reforms in China and Hong Kong. International Review of Administrative Sciences, 78(22): 261-283.

Christensen $\mathrm{T}$ and Lægreid P (2007) Transcending New Public Management. The transformation of public sector reforms. Aldershot: Ashgate.

Christensen $\mathrm{T}$ and Lægreid P (2011) Complexity and hybrid public administration: Theoretical and empirical challenges. Public Organization Review, 11: 407-23. 
Dunleavy PJ and Hood C (1994) From old Public Administration to New Public Management. Public Money and Management, 14(3): 9-16.

Etherington LD and Richardson AJ (1994) Institutional pressures on university accounting education in Canada. Contemporary Accounting Research, 10: 141-62.

Fairclough N (2003) Analysing discourse, London: Routledge.

Fattore G, Dubois HFW and Lapenta A (2012) Measuring New Public Management and Governance in political debate. Public Administration Review, 72(2): 218-227.

Ferlie E, Ashburner L, Fitzgerald L and Pettigrew A (1996) The New Public Management in Action. Oxford: Oxford University Press.

Fischer F (2003) Reframing Public Policy: discursive politics and deliberative practices. Oxford: Oxford University Press.

Guthrie J, Johanson U, Bukh PN and Sànchez P (2003) Intangibles and the transparent enterprise: new strands of knowledge. Journal of Intellectual Capital, 4(4): 429-40.

Greenwood R and Hinings CR (1993) Understanding strategic change: the contribution of archetypes, The Academy of Management Journal, 36(5): 1052-81.

Greenwood R and Hinings CR (1996) Understanding radical organizational change: bringing together the old and the new institutionalism, Academy of Management Review, 21(4): 102254.

Hammerschmid G and Meyer RE (2005) New Public Management in Austria: Local variation on a global theme? Public Administration, 83: 709-33.

Hardy C (2011) Researching organizational discourse. International Studies of Management and Organization, 31(3): 25-47.

Hyndman N., Liguori M, Meyer RE, Polzer T, Rota S, Seiwald J (2014) The translation and sedimentation of accounting reforms. A comparison of the UK, Austrian and Italian experiences. Critical Perspectives on Accounting, 25(4-5): 388-408.

Hinings CR and Greenwood R (1988) The dynamics of strategic change. Oxford: Basil Blackwell.

Hood C (1991) A Public Management for all seasons?. Public Administration, 69(1): 3-19. 
Hood C (1995) The "New Public Management" in the 1980s: Variations on a Theme? Organizations, Accounting and Society, 20 (2-3): 93-109.

Kickert WJM (2005) Distinctiveness in the study of Public Management in Europe. A historical-institutional analysis of France, Germany and Italy. Public Management Review, 7(4): 537-563.

Kickert WJM (2008) Distinctiveness in the study of Public Management in Europe. The study of Public Management in Europe and the US. A comparative analysis of national distinctiveness. London: Routledge, pp. 1-13.

Krippendorff K (1980) Content Analysis: An Introduction to Its Methodology. Beverly Hills: The Sage CommText Series, Sage.

Kuhlmann S (2010) Performance Measurement in European local governments: a comparative analysis of reform experiences in Great Britain, France, Sweden and Germany. International Review of Administrative Sciences, 76(2,): 331-345.

Lapsley I. (1999) Accounting and the new public management: Instruments of substantive efficiency or a rationalising modernity?. Financial Accountability and Management, 10: 2018.

Lapsley I (2008) The NPM agenda: Back to the future. Financial Accountability \& Management, 24: 77-96.

Lapsley I (2009) New Public Management: The Cruellest Invention of the Human Spirit? Abacus, 45(1): 1-21.

Liguori M (2012a) Radical change, accounting and public sector reforms: A comparison of Italian and Canadian municipalities. Financial, Accountability and Management, 28(4): 437463.

Liguori M (2012b) The supremacy of the sequence: Key elements and dimensions in the process of change. Organization Studies, 33: 507-39.

Liguori M and Steccolini I (2012) Accounting change: explaining the outcomes, interpreting the process. Accounting, Auditing \& Accountability Journal, 25(1): 27-70.

Liguori M and Steccolini I (2014) Accounting, innovation and public-sector change. Translating reforms into change? Critical Perspectives on Accounting, 25(4-5): 319-323. 
Liguori M, Sicilia M and Steccolini I (2012) Some like it non-financial...Politicians' and managers' views on the importance of performance information. Public Management Review, 14(7): 903-22.

Loughran T and McDonald B (2011) When is a liability not a liability? Textual analysis, dictionaries, and 10 - Ks. The Journal of Finance, 66(1): 35-65.

Lounsbury M (2001) Institutional sources of practice variation: Staffing college and university recycling programs. Administrative Science Quarterly. 46: 29-56.

Lynn L and Heinrich C (2001) Improving governance. A new logic for empirical research. Washington, DC: Georgetown University Press.

Marsh D and Rhodes R (1992) Policy Networks in British Government. Oxford: Clarendon Press.

Marty F, Trosa S and Voisin A (2006). The move to Accrual Based Accounting: the challenges facing central governments. International Review of Administrative Sciences, 72: 203, pp. 203-221.

McNulty $\mathrm{T}$ and Ferlie E (2004). Reeingineering Health Care: The Complexities of Organizational Transformation. NY: Oxford University Press.

McGrath R (2009) A discourse analysis of Australian local government recreation and sport plans provision for people with disabilities. Public Management Review, 11(4): 477-497.

Mills CW (1940) Situated actions and vocabularies of motive. American Sociological Review, 5(6): 904-913.

Milne M and Adler R (1999) Exploring the reliability of social and environmental disclosures content analysis. Accounting, Auditing \& Accountability Journal, 12(2): 237-56.

Milward D and Provan K (2003) Managing the Hollow State. Collaboration and contracting. Public Management Review, 5(1): 1-18.

Tomasi di Lampedusa G (1960) The Leopard (Il Gattopardo). First English Language edition, New York: Pantheon.

O'Connor ES (1995) Paradoxes of participation: Textual analysis and organizational change. Organization Studies, 16(5): 769-803.

Olson O, Guthrie J and Humphrey C (1998) Global Warning! Debating international developments in New Public Financial Management. Oslo: Cappelen Akademisk Forlag. 
Ongaro E (2011) The role of politics and institutions in the Italian administrative reform trajectory. Public Administration, 89: 738-55.

Osborne SP (2006) The New Public Governance?. Public Management Review, 8: 377-87.

Osborne SP (2010) Introduction. The (New) Public Governance: A suitable case for treatment? The New Public Governance? Emerging perspectives on the theory and practice of Public Governance. London and New York: Routledge.

O'Toole LJ and Meier KJ (2014) Public management, context, and performance: in quest of a more general theory. Journal of Public Administration Research and Theory, 1: 1-20.

Panozzo F (1998) Management by decree. Paradoxes in the reform of the Italian public sector. Scandinavian Journal of Management, 16(4): 357-373.

Peters G (2008) The two futures of governing: Decentering and recentering processes in governing. Pittsburgh: University of Pittsburgh Press.

Pollitt C (2001) Convergence. The useful myth? Public Administration, 79: 933-47.

Pollitt C and Bouckaert G (2004) Public sector reform. A comparative analysis. Oxford: Oxford University Press.

Pollitt C and Bouckaert G (2011) Public sector reform. A comparative analysis: New Public Management, Governance, and the Neo-Weberian State. 3rd ed. Oxford: Oxford University Press.

Rhodes RAW (1997) Understanding governance. Policy networks, governance, reflexivity and accountability. Buckingham: Open University Press.

Romanelli E and Tushman ML (1994) Organizational transformation as punctuated equilibrium: an emprical test. Academy of Management Journal, 37:1141-66.

Sabatier P (1999) The Need for Better Theories. In P. Sabatier (ed.), Theories of the Policy Process. Boulder: Westview Press.

Schedler K and Proeller I (eds) (2007) Cultural aspects of Public Management reform. Amsterdam: Elsevier.

Skelcher C, Mathur N and Smith M (2005) The Public Governance Of Collaborative Spaces: Discourse, Design And Democracy. Public Administration, 83(3): 573-596. 
Van Thiel S (2014) Research Methods in Public Administration and Public Management: An Introduction, London and New York: Routledge.

Weber M (1922) Bureaucracy. In Shafritz JM and Hyde AC (eds) Classics of public administration. Orlando: Harcourt Brace College Publishers.

Wilson W (1887) The Study of Administration. Political Science Quarterly, 2: 197-22. 
Tables

TABLE 1 Accounting reforms in Italy: an overview

\begin{tabular}{|c|c|c|c|}
\hline & $1980 \mathrm{~s}$ & $1990 \mathrm{~s}$ & $2000 \mathrm{~s}$ \\
\hline $\begin{array}{l}\text { Structures and } \\
\text { systems of the } \\
\text { accounting } \\
\text { reforms }\end{array}$ & $\begin{array}{l}\text { - Co-existence of cash and commitment } \\
\text { systems derived from the past. } \\
\text { Main principles: budgetary compliance and } \\
\text { control over expenditures. } \\
\text { Accounting documents: the budget, the } \\
\text { three-year budget and the financial law. } \\
1988 \text { Introduction of EFP (Economic and } \\
\text { Financial Plan) in order to focus on } \\
\text { programmes and set clear financial } \\
\text { objectives over the three-year period of the } \\
\text { long-term budget (Law n. 362). }\end{array}$ & $\begin{array}{l}\text { - } 1997 \text { Revision of the budget in two distinct functions } \\
\text { (political and managerial). Consequent reclassification } \\
\text { of revenues and expenditures (Law n. 94). } \\
1997 \text { Introduction of accrual budgeting, although only } \\
\text { traditional cash- and commitment-based budgets that } \\
\text { have to be approved by Parliament. } \\
\text { Phases of the accrual budget: } \\
\text { - proposed budget (ministries account for their } \\
\text { financial and human resources needs) } \\
\text { - presented budget (updated financial figures) } \\
\text { - definite budget (objectives are reconsidered and } \\
\text { adjusted to costs). "Objectives-resources-results" } \\
\text { efficiency paradigm introduced. } \\
\text { Accrual financial statement gives more focus on non- } \\
\text { financial results: cost accounting items directly related } \\
\text { to efficiency and effectiveness indicators as identified } \\
\text { by each ministry (Legislative Decree } 94 \text { ). }\end{array}$ & $\begin{array}{l}\text { - } 2007 \text { Reorganisation of the cash- and commitment- } \\
\text { based budget on missions and programmes: } \\
\text { - missions (the main functions and pursued strategic } \\
\text { objectives) define the new political structure of the } \\
\text { budget (ministries' responsibility) } \\
\text { - programmes represent the realisation of missions } \\
\text { (areas or homogeneous activities for the } \\
\text { achievement of specific objectives). } \\
2007 \text { Partial revision of cost accounting system with } \\
\text { further detail on chart of accounts (costs recorded by } \\
\text { nature, centre, mission and programme - mirroring } \\
\text { the accrual budget). Organisational structure and cost } \\
\text { centre changes. Annual spending review introduced. } \\
2009 \text { Commitment-based budgeting abandoned in } \\
\text { favour of a two-year experimentation drawing on cash } \\
\text { only (Law n. 196). }\end{array}$ \\
\hline $\begin{array}{l}\text { Official } \\
\text { documents }\end{array}$ & $\begin{array}{l}\text { - Transcript from the Chamber of Deputies } \\
\text { discussion, Law } 362 / 1988 \\
\text { - Transcript from the Senate discussion, Law } \\
362 / 1988 \\
\text { - Law } 362 / 1988\end{array}$ & $\begin{array}{l}\text { - Transcript from the Senate Committee discussion, } \\
\text { Law 94/1997 } \\
\text { - Transcript from the Chamber of Deputies Committee, } \\
\text { Law 94/1997 (9 documents) } \\
\text { - Transcript from the first Senate discussion, Law } \\
\text { 94/1997 } \\
\text { - Transcript from the Chamber of Deputies discussion, } \\
\text { Law 94/1997 } \\
\text { - Transcript from the second Senate discussion and } \\
\text { approval, Law 94/1997 } \\
\text { - Law 94/1997 } \\
\text { - Legislative Decree 279/1997 } \\
\text { - 'Circolare' 81/1997 } \\
\text { - 'Circolare' 32/1999 }\end{array}$ & 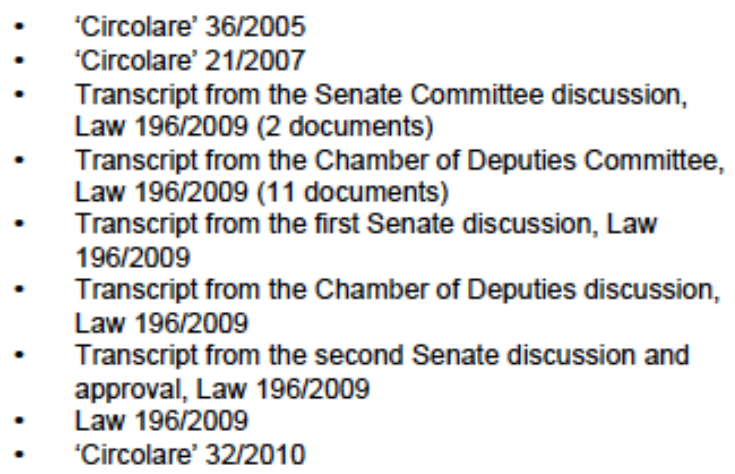 \\
\hline
\end{tabular}


TABLE 2 Occurrence of discourse cues, 1988-2010

\begin{tabular}{|c|c|c|c|c|c|c|c|c|}
\hline & PA1 & PA2 & NPM1 & NPM2 & GoV1 & GOV2 & $\begin{array}{c}\text { TOTAL } \\
\text { COUNTS }\end{array}$ & $\begin{array}{c}\text { TOTAL } \\
\text { DOCUMENTS }\end{array}$ \\
\hline \multirow{2}{*}{1988} & 677 & 21 & 292 & 37 & 29 & 7 & 1,063 & \multirow{2}{*}{3} \\
\hline & $63.7 \%$ & $2 \%$ & $27.5 \%$ & $3.5 \%$ & $2.7 \%$ & $0.7 \%$ & $100.0 \%$ & \\
\hline \multirow{2}{*}{1997} & 1260 & 34 & 770 & 22 & 147 & 3 & 2,236 & \multirow{2}{*}{16} \\
\hline & $56.4 \%$ & $1.5 \%$ & $34.4 \%$ & $1 \%$ & $6.6 \%$ & $0.1 \%$ & $100 \%$ & \\
\hline \multirow{2}{*}{1999} & 130 & 6 & 281 & 0 & 6 & 0 & 423 & \multirow{2}{*}{1} \\
\hline & $31.2 \%$ & $1.4 \%$ & $67.4 \%$ & $0 \%$ & $0 \%$ & $0 \%$ & $100 \%$ & \\
\hline \multirow{2}{*}{2005} & 43 & 1 & 38 & 0 & 2 & 0 & 84 & \\
\hline & $52.4 \%$ & $1.2 \%$ & $46.3 \%$ & $0 \%$ & $0 \%$ & $0 \%$ & $100 \%$ & \\
\hline \multirow{2}{*}{2007} & 32 & 0 & 25 & 0 & 5 & 0 & 62 & \multirow{2}{*}{1} \\
\hline & $51.6 \%$ & $0 \%$ & $40.3 \%$ & $0 \%$ & $8.1 \%$ & $0 \%$ & $100 \%$ & \\
\hline \multirow{2}{*}{2009} & 2,684 & 34 & 1,787 & 51 & 435 & 34 & 5,025 & \multirow{2}{*}{17} \\
\hline & $53.4 \%$ & $0.7 \%$ & $35.6 \%$ & $1 \%$ & $8.7 \%$ & $0.7 \%$ & $100 \%$ & \\
\hline \multirow{2}{*}{2010} & 40 & 0 & 6 & 0 & 2 & 0 & 48 & \multirow{2}{*}{1} \\
\hline & $81.6 \%$ & $0 \%$ & $12.2 \%$ & $0 \%$ & $2 \%$ & $4.1 \%$ & $100 \%$ & \\
\hline
\end{tabular}

TABLE 3 Discourse co-occurrences, normalised by the number of documents per year, $1988-2010$.

\begin{tabular}{|c|c|c|c|c|c|c|}
\hline 1988 & GOV1 & & & & & \\
\hline GOV2 & 0.00 & GOV2 & & & & \\
\hline NPM1 & 2.33 & 0.33 & NPM1 & & & \\
\hline NPM2 & 0.00 & 0.00 & 2.00 & NPM2 & & \\
\hline PA1 & 5.67 & 0,67 & 47.33 & 5.33 & PA1 & \\
\hline PA2 & 0.67 & 0.00 & 4.00 & 1.33 & 3.33 & PA2 \\
\hline
\end{tabular}

\begin{tabular}{|c|c|c|c|c|c|c|}
\hline 1997 & GOV1 & & & & & \\
\hline GOV2 & 0.00 & GOV2 & & & & \\
\hline NPM1 & 6.06 & 0.13 & NPM1 & & & \\
\hline NPM2 & 0.25 & 0.00 & 0.19 & NPM2 & & \\
\hline PA1 & 8.38 & 0.13 & 21.00 & 0.56 & PA1 & \\
\hline PA2 & 0.13 & 0.00 & 1.38 & 0.00 & 1.00 & PA2 \\
\hline
\end{tabular}

\begin{tabular}{|c|c|c|c|c|c|c|}
\hline 1999 & GOV1 & & & & & \\
\hline GOV2 & 0.00 & GOV2 & & & & \\
\hline NPM1 & 7.00 & 0.00 & NPM1 & & & \\
\hline NPM2 & 0.00 & 0.00 & 0.00 & NPM2 & & \\
\hline PA1 & 4.00 & 0.00 & 139.00 & 0.00 & PA1 & \\
\hline PA2 & 2.00 & 0.00 & 8.00 & 0.00 & 4.00 & PA2 \\
\hline
\end{tabular}

\begin{tabular}{|c|c|c|c|c|c|c|}
\hline 2005 & GOV1 & & & & & \\
\hline GOV2 & 0.00 & GOV2 & & & & \\
\hline NPM1 & 3.00 & 0.00 & NPM1 & & & \\
\hline NPM2 & 0.00 & 0.00 & 0.00 & NPM2 & & \\
\hline PA1 & 2.00 & 0.00 & 24.00 & 0.00 & PA1 & \\
\hline PA2 & 0.00 & 0.00 & 1.00 & 0.00 & 1.00 & PA2 \\
\hline
\end{tabular}

\begin{tabular}{|c|c|c|c|c|c|c|}
\hline 2007 & GOV1 & & & & & \\
\hline GOV2 & 0.00 & GOV2 & & & & \\
\hline NPM1 & 1.00 & 0.00 & NPM1 & & & \\
\hline NPM2 & 0.00 & 0.00 & 0.00 & NPM2 & & \\
\hline PA1 & 2.00 & 0.00 & 11.00 & 0.00 & PA1 & \\
\hline PA2 & 0.00 & 0.00 & 1.00 & 0.00 & 0.00 & PA2 \\
\hline
\end{tabular}

\begin{tabular}{|c|c|c|c|c|c|c|}
\hline 2009 & GOV1 & & & & & \\
\hline GOV2 & 0.47 & GOV2 & & & & \\
\hline NPM1 & 19.18 & 1.53 & NPM1 & & & \\
\hline NPM2 & 0.71 & 0.35 & 1.76 & NPM2 & & \\
\hline PA1 & 20.82 & 1.82 & 58.06 & 2.35 & PA1 & \\
\hline PA2 & 0.76 & 0.06 & 1.65 & 0.29 & 1.88 & PA2 \\
\hline
\end{tabular}

\begin{tabular}{|c|c|c|c|c|c|c|}
\hline 2010 & GOV1 & & & & & \\
\hline GOV2 & 3.00 & GOV2 & & & & \\
\hline NPM1 & 34.00 & 4.00 & NPM1 & & & \\
\hline NPM2 & 2.00 & 4.00 & 5.00 & NPM2 & & \\
\hline PA1 & 37.00 & 8.00 & 132.00 & 7.00 & PA1 & \\
\hline PA2 & 0.00 & 0.00 & 3.00 & 1.00 & 3.00 & PA2 \\
\hline
\end{tabular}




\section{Figures}

FIGURE $1 P A, N P M$ and GOV evolution, 1988-2010

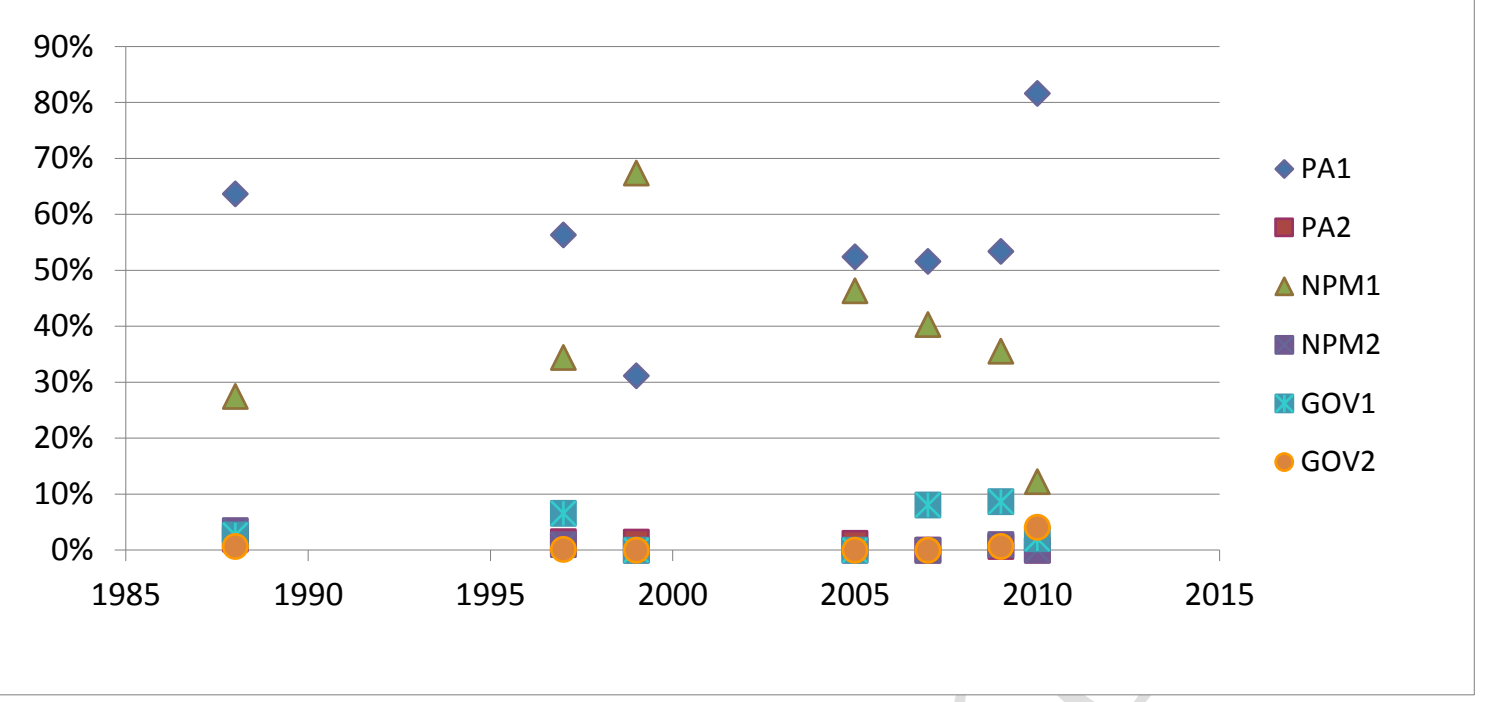


Appendix

\begin{tabular}{|c|c|c|c|}
\hline Archetypes & PA & NPM & GoV \\
\hline \multirow{7}{*}{$\begin{array}{l}\text { Main ideas and } \\
\text { values }\end{array}$} & Public administration (citizens) & Service provider (customers) & Governance and market rules setter (stakeholders) \\
\hline & Based on professional differentiation & Based on the integration of professional activities & Based on negotiation of values, meanings and relationships \\
\hline & $\begin{array}{l}\text { Professional practice defined by intra- } \\
\text { jurisdictional professionals }\end{array}$ & Analytical appraisal by trans-jurisdictional management & Enablement skills: Activation, Orchestration, Modulation \\
\hline & Public administration as a closed system & Public administration as an open system & $\begin{array}{l}\text { Public administration as an 'open closed' system (external focus } \\
\text { but providing enclosing regulation of public services) }\end{array}$ \\
\hline & Constitutive role of legitimacy & Performance-driven legitimacy & $\begin{array}{l}\text { Legitimacy through negotiated agreements and the mechanism } \\
\text { of democratic accountability }\end{array}$ \\
\hline & $\begin{array}{l}\text { Objectives selected in accordance with } \\
\text { political rationality }\end{array}$ & $\begin{array}{l}\text { Objectives selected in accordance with economic and } \\
\text { organizational rationality }\end{array}$ & $\begin{array}{l}\text { Objectives selected in accordance with networking and } \\
\text { negotiation with different actors }\end{array}$ \\
\hline & $\begin{array}{l}\text { Neutral and objective administrative activity, } \\
\text { separated from politics and executing law }\end{array}$ & $\begin{array}{l}\text { Administrative activity interacting with politics: politics sets } \\
\text { strategy, managers reach objectives }\end{array}$ & $\begin{array}{l}\text { Administrative activity interacting with the environment: } \\
\text { systematic and effective consultations with stakeholders }\end{array}$ \\
\hline \multirow{6}{*}{$\begin{array}{l}\text { Structures and } \\
\text { systems }\end{array}$} & High differentiation and low integration & Modest differentiation and high integration & Integration of people, processes, structures, and resources \\
\hline & Incremental resource allocation system & Non-incremental resource allocation system & $\begin{array}{l}\text { Inter-organizational and negotiated resource allocation (shared } \\
\text { and agreed by multiple actors with different power) }\end{array}$ \\
\hline & Hierarchical bureaucratic control system & Decentralized control system & $\begin{array}{l}\text { Inter-organizational control systems with different scope and } \\
\text { tightness (private, public and social actors) }\end{array}$ \\
\hline & $\begin{array}{l}\text { Internal organization untied to selected } \\
\text { objectives }\end{array}$ & Internal organization tied to selected objectives & $\begin{array}{l}\text { External organization and network of actors tied to negotiated } \\
\text { objective }\end{array}$ \\
\hline & Focus on formal procedures & Focus on processes and results (input-output) & $\begin{array}{l}\text { Focus on 'steering' of complex networks in societal policy } \\
\text { sectors }\end{array}$ \\
\hline & Formal evaluation, based on regulation & Efficiency and effectiveness evaluation & $\begin{array}{l}\text { Governance of citizen engagement, transparency, } \\
\text { accountability, equity (fair procedures and due process), } \\
\text { partnership, sustainability and } \\
\text { impact of public services }\end{array}$ \\
\hline
\end{tabular}




\begin{tabular}{|c|c|c|c|}
\hline Archetypes & PA & NPM & GOV \\
\hline \multirow{6}{*}{$\begin{array}{l}\text { Accounting } \\
\text { structures and } \\
\text { systems }\end{array}$} & $\begin{array}{l}\text { Main purpose: to limit spending; to show } \\
\text { compliance of actions with budget }\end{array}$ & Main purpose: to orient behaviours toward goal attainment & Main purpose: to answer stakeholders' needs \\
\hline & Basis: obligation and cash & Basis: accruals & - \\
\hline & Focus: financial indicators and inputs & Focus: performance indicators, outputs & Focus: outcomes, transparency and accountability \\
\hline & Tools: budgetary accounting & $\begin{array}{l}\text { Tools: executive budget, accrual - based reporting, managerial } \\
\text { control systems, performance measurement }\end{array}$ & $\begin{array}{l}\text { Tools: consolidated statements, social/sustainability reporting, } \\
\text { stakeholders' reports }\end{array}$ \\
\hline & $\begin{array}{l}\text { Centralized data gathering, information } \\
\text { processing and use (Finance Officer) }\end{array}$ & $\begin{array}{l}\text { Decentralized data gathering, information processing and use; } \\
\text { integrated accounting system }\end{array}$ & $\begin{array}{l}\text { Data gathering from different actors of the network, inter- } \\
\text { organizational integration of information systems }\end{array}$ \\
\hline & Finance Officer & Audit control/Controller/integrated management & 'Network manager' as conductor, intermediator and facilitator \\
\hline $\begin{array}{l}\text { Selected } \\
\text { keywords for } \\
\text { discourse } \\
\text { analysis }\end{array}$ & $\begin{array}{l}\text { ! Bureaucratic/bureaucracy } \\
\text { ! Citizen } \\
\text { ! Rule/norm/requirement } \\
\text { ! Compliance } \\
\text { ! Cash/commitments } \\
\text { ! 'Funzionario/pubblico } \\
\text { ufficiale'/administrator/ bureaucrat } \\
! \text { Execute/ executor } \\
\text { ! Hierarchy/ hierarchical } \\
\text { ! Neutral } \\
\text { ! Objectivity/ objective } \\
\text { ! Expenditure/spending } \\
\text { ! Procedures } \\
\text { ! Central(ised) } \\
\text { ! Function } \\
\text { ! Inflexibility/rigidity } \\
\text { ! Overregulation } \\
\text { ! Independence }\end{array}$ & $\begin{array}{l}\text { ! NPM/managerialisation } \\
\text { ! Efficiency } \\
\text { ! Effectiveness } \\
\text { ! Output/results } \\
\text { ! Outcomes } \\
\text { ! } \text { Customers/client } \\
\text { ! Managers/managerial } \\
\text { ! Strategy } \\
\text { ! Performance/performance } \\
\text { ! Measures/indicator/target/objective/to measure } \\
\text { ! Satisfaction } \\
\text { ! Accruals/resources/value for money } \\
\text { ! Contract } \\
\text { ! } \text { Euality/appropriateness } \\
\text { ! Audit/auditing } \\
\text { ! Cost/ amortisation } \\
\text { ! Process } \\
\text { ! Flexibility } \\
\text { ! Recentralised/devolved } \\
\text { ! Pesponsible/responsibility } \\
\text { ! Pablic business' } \\
\text { ! Corporatization/agencies/agencification } \\
\text { ! Competition/tendering/benchmarking } \\
\text { ! Privatization } \\
\text { ! Deregulation }\end{array}$ & $\begin{array}{l}\text { ! Governance } \\
\text { ! Transparency } \\
\text { ! Accountability } \\
\text { ! Outcomes } \\
\text { ! Stakeholder } \\
\text { ! Network } \\
\text { ! Partnership/partners } \\
\text { ! Sustainability/sustainable } \\
\text { ! Ethic } \\
\text { ! Equity/fair } \\
\text { ! Participation/participative } \\
\text { ! Integration/integrated } \\
\text { ! Satisfaction, } \\
\text { ! Consolidation/consolidated } \\
\text { ! Negotiation/consultation } \\
\text { ! Civil society/non profit/third sector }\end{array}$ \\
\hline
\end{tabular}

